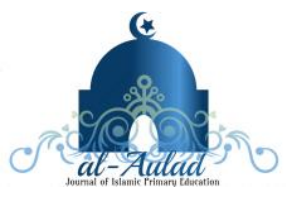

\title{
ANALISIS LEARNING OBSTACLES SISWA PADA MATERI PECAHAN KELAS IV SEKOLAH DASAR
}

\author{
Siti Khazanatu Rohmah ${ }^{1}$

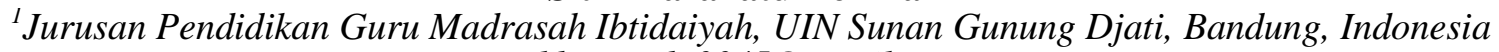 \\ khozanah.0045@gmail.com
}

Naskah diterima: 1 Februari, 2019, direvisi:14 Maret, 2018, diterbitkan: 31 Maret, 2019

\begin{abstract}
The purpose of this research to analyze errors of students answer to get a conception of learning obstacles in the fraction material in $4^{\text {th }}$ grade of elementary school. This analysis is important as a basis to prepare teaching materials and to predict of student responses and how to anticipate. This research used the qualitative method. The research subjects were 32 student of $5^{\text {th }}$ grade elementary school who had studied fractions in grade IV in Tasikmalaya Regency. Based on the results of analysis of test and interview data, there are several barriers on student learning. First, didactical obstacles were identified from mistake doing the test problems which is caused by how students studied and materials which used by students such as fraction material that did not clearly define how fractions was and emphasize knowledge procedures, then students do not study fractions through the partitioning process, somewhere partitioning will make learning easier. Second, epistemological obstacles as a result from errors in the processing of questions caused by the limited context of knowledge possessed by students. For example, the definition of fractions which are part of the whole, students are limited to that context without paying attention at the parts as equal/more or less. In addition, procedures of student understanding for example fraction simplification, fraction sequencing, and subtraction and addition of fractions are limited to certain questions. When the questions are different than usual, there are students who didn't understand the purpose of the problem.
\end{abstract}

Keywords: fractions, learning obstacles, epistemological obstacle, didactical obstacles.

\begin{abstract}
ABSTRAK
Penelitian ini bertujuan untuk menganalisis kesalahan jawaban siswa untuk memperoleh gambaran hambatan belajar (learning obstacles) siswa pada materi pecahan kelas IV Sekolah Dasar. Analisis ini penting dilakukan sebagai landasan untuk menyiapkan bahan ajar serta prediksi respon siswa terhadap pembelajaran yang akan dilakukan dan cara antisipasinya. Metode yang digunakan dalam penelitian ini adalah metode kualitatif. Subjek penelitiannya adalah 32 siswa Sekolah Dasar kelas V yang telah mempelajari pecahan di kelas IV di Kabupaten Tasikmalaya. Berdasarkan hasil analisis data tes dan wawancara terdapat beberapa hambatan belajar siswa, diantaranya adalah pertama, didactical obstacles teridentifikasi dari kesalahan-kesalahan pengerjaan soal yang diakibatkan oleh bagaimana siswa belajar dan bahan ajar yang digunakan siswa seperti pembelajaran pecahan yang tidak mendefinisikan pecahan secara jelas dan menekankan pada pengetahuan prosedur prosedural, kemudian siswa tidak mempelajari pecahan lewat proses partisi terlebih dahulu, dimana mempartisi akan memudahkan siswa dalam mempelajari pecahan. Kedua, epistimological obstacles muncul dari kesalahan-kesalah pengerjaan soal yang diakibatkan oleh keterbatasan konteks pengetahuan yang dimiliki siswa. Misalnya, pengertian pecahan yang merupakan bagian dari keseluruhan, siswa terbatas pada konteks tersebut tanpa memandang bagian-bagiannya sama besar/banyak atau tidak. Selain itu, pemahaman prosedur siswa mengenai penyederhanaan pecahan, pengurutan pecahan,
\end{abstract}


serta pengurangan dan penjumlahan pecahan terbatas pada soal-soal tertentu. Ketika soal yang diberikan berbeda dari biasanya, terdapat siswa yang kurang memahami maksud soal.

Kata Kunci: pecahan, learning obstacles, epistemological obstacle, didactical obstacles.

\section{PENDAHULUAN}

Salah satu materi penting dalam matematika adalah bilangan. Verschaffel, Greer, dan De Corte (Pitta-Pantazi, 2014, hlm. 471) mengemukakan beberapa alasan mengapa bilangan begitu penting dipelajari siswa, di antaranya: (1) operasi dan aplikasi dari bilangan berhubungan dengan kehidupan nyata dan digunakan di dalamnya; (2) bilangan merupakan dasar dari berbagai macam materi dalam matematika; (3) bilangan merupakan salah satu materi pertama yang diajarkan di sekolah secara formal. Pecahan merupakan bagian dari bilangan. Pecahan menjadi landasan bagi siswa dalam mempelajari matematika selanjutnya seperti persen, rasio, dan aljabar. Kurangnya pemahaman siswa dalam pecahan dapat mengakibatkan kesulitan bagi siswa dalam memecahkan masalah matematika lainnya. Behr dan Post (Wheeldon, 2008, hlm. 7) menyatakan siswa dapat mengalami kesulitan dalam mempelajari aljabar karena kurangnya pemahaman mereka dalam pecahan. Selain itu, menurut Wu (1998) tidak didefinisikan dan dimaknainya pecahan dengan jelas akan menimbulkan kebingungan dalam memahami rasio, proporsi, ataupun persen.

Pecahan penting bagi siswa, namun beberapa kesulitan masih sering muncul ketika mempelajarinya. Kesulitan itu di antaranya sulit melihat pecahan sebagai sebuah bilangan, tetapi melihat pecahan sebagai dua bilangan yang dipisahkan dengan garis di antara keduanya. Beberapa siswa kadang menjumlahkan pecahan dengan cara menjumlahkan penyebut dengan penyebut serta pembilang dengan pembilang (Behr, dkk. (dalam PittaPantazi, 2014); Walle, 2010; Sadi, 2007). Kesulitan yang muncul lainnya adalah siswa memahami pecahan dalam bentuk $\frac{a}{b}$ sebagai a bagian dari keseluruhan b bagian yang tidak sama besar (Pitta-Pantazi, 2014). Dalam memahami pecahan yang senilai menurut Sadi (2007) beberapa siswa tidak bisa menemukan hubungan antara kesetaraan dan ukuran dua pecahan yang diberikan. Begitu pun dalam mengerjakan soal pecahan dalam bentuk cerita, menurut Untari (2013, hlm. 7) terdapat kesulitan siswa dalam mengerjakan soal cerita yang terkait dengan pecahan. Brousseau (2002) menjelaskan kesulitan atau hambatan siswa dalam mempelajari pecahan dapat dipengaruhi oleh strategi guru mengajar (didactical obstacle), struktur isi matematika (epistimological obstacle), maupun hambatan yang muncul dari kemampuan kognitif siswa (ontogenic obstacle).

Hambatan ontogeni (ontogenetic obstacles) terjadi karena proses pembelajaran yang tidak sesuai dengan kesiapan siswa. Hambatan ini erat kaitannya dengan perkembangan mental siswa yang dihubungkan dengan faktor usia dan tingkat perkembangan (Manno, 2005; Cortina, Visnovska, dan Zuniga, 2014; Nyikahadzoyi, Mapuwei, dan Chinyoka, 2013) Jika hambatan belajar muncul karena perkembangan mental yang lambat dan bukan karena penyakit bawaan, maka hambatan itu akan hilang dengan sendirinya seiring dengan pertumbuhan siswa tersebut (Manno, 2005).

Hambatan didaktis (didactical obstacles) merupakan hambatan yang terjadi akibat kekeliruan proses pembelajaran yang berasal dari sistem pembelajaran di sekolah atau berasal dari strategi guru yang digunakan dalam mempelajari ide matematika tertentu (Manno, 2005; Cortina, Visnovska, dan Zuniga, 2014; Prediger, 2008; Nyikahadzoyi, Mapuwei, dan Chinyoka, 2013). Dengan demikian, menemukan strategi pembelajaran untuk materi matematika tertentu agar siswa tidak mengalami hambatan ataupun kesulitan dalam 
memahami materi tersebut sangat penting dilakukan (Cortina, Visnovska, dan Zuniga, 2014).

Hambatan epistimologis (epistemological obstacles) pada hakikatnya merupakan pengetahuan siswa yang hanya terbatas pada konteks tertentu. Jika siswa tersebut dihadapkan pada konteks berbeda, pengetahuan yang dimiliki menjadi tidak dapat digunakan atau ia mengalami kesulitan untuk menggunakannya (Manno, 2005; Cortina, Visnovska, dan Zuniga, 2014; Prediger, 2008; Nyikahadzoyi, Mapuwei, dan Chinyoka, 2013). Dalam hal ini, pandangan siswa terhadap konsep yang satu dengan konsep yang lain terputus-putus dan tidak komprehensif.

Ketiga learning obstacles yang dikemukakan di atas dapat menjadi pertimbangan dalam mengembangkan desain pembelajaran, terutama dalam menyusun antisipasi didaktis dan pedagogis. Dengan pertimbangan ontogenic obstacles dapat dirancang pembelajaran yang sesuai dengan tingkat perkembangan peserta didik. Dengan pertimbangan epistemological obstacles dapat dirancang pembelajaran yang menggunakan beragam konteks agar siswa menyadari bahwa pengetahuan yang dimilikinya bersifat fleksibel. Dengan mempertimbangkan didactical obstacles dapat disusun lintasan belajar dan stategi pembelajaran yang alternatif bagi siswa.

Penelitian ini dilakukan untuk melihat apakah terdapat hambatan pada siswa baik ontologis, didaktis, maupun epistimologis pada materi pecahan. Hasil penelitian dapat dijadikan pertimbangan bagi guru dalam menyususun desain didaktis atau dalam merencanakan pembelajaran materi pecahan di kelas IV SD.

\section{METODOLOGI}

Metode penelitian yang digunakan adalah metode kualitatif. Metode ini dipilih karena untuk mengidentifikasi learning obstacle membutuhkan kajian mendalam terhadap jawaban yang diberikan siswa dalam tes yang diberikan, proses berpikir siswa, serta maksud dan pengalaman siswa dalam mempelajari materi yang diujikan. Oleh karena itu, dibutuhkan suatu metode yang dapat mengungkapkan secara rinci gejala atau fenomena yang sulit jika diungkapkan dengan menggunakan metode kuantitatif.

Penelitian ini dilakukan di kelas V salah satu sekolah dasar di Kabupaten Tasikmalaya, dengan 32 orang siswa sebagai partisipan. Tahapan yang dilakukan dalam penelitian ini adalah: (1) mengujicobakan instrumen test learning obstacles kepada siswa yang pernah belajar materi pecahan; (2) mengamati pengerjaan instrumen oleh siswa; (3) mengadakan wawancara kepada siswa mengenai instrumen tes yang telah diujicobakan; (4) mengolah dan menjabarkan hasil yang diperoleh dari uji coba instrumen dan wawancara; (5) menguraikan learning obstacles yang muncul pada siswa berdasarkan uji coba instrumen tes pada materi pecahan; (6) mengadakan wawancara kepada guru yang mengajarkan pecahan kelas IV; (7) menganalisis data dengan mengklasifikasikan temuan pada didactical obstacle, epistimological obstacle, dan ontogenic obstacle, sesuai dengan karakteristiknya. (8) membuat kesimpulan.

\section{HASIL DAN DISKUSI}

Beberapa soal diberikan kepada 32 siswa kelas V SD N Cikeupeul di Kabupaten Tasikmalaya yang telah mempelajari pecahan di kelas IV. Hal ini dilakukan untuk memperoleh gambaran mengenai learning obstacles yang dihadapi pada materi pecahan. Learning obstacles diperoleh dengan menganalisis hasil jawaban siswa dan wawancara terhadap siswa. 
Pengelompokan hasil jawaban siswa didasarkan pada kompetensi dasar materi pecahan kelas IV yaitu menjelaskan arti pecahan dan urutannya, menyederhanakan berbagai bentuk pecahan, menjumlahkan pecahan, mengurangkan pecahan, dan menyelesaikan masalah yang berkaitan dengan pecahan. Menyelesaikan masalah yang berkaitan dengan pecahan tidak dibahas secara khusus karena semua soal yang diberikan merupakan masalah keseharian siswa. Adapun arti pecahan menggunakan empat makna dari pecahan di sekolah dasar, keempat makna tersebut menurut Sonnabend (2010) yaitu: (1) pecahan sebagai bagian dari keseluruhan utuh, (2) pecahan sebagai bagian dari himpunan tertentu, (3) pecahan menempati sebuah titik dari garis bilangan, dan (4) pecahan sebagai pembagian atau hasil bagi. Dengan demikian hasil analisis jawaban yang diberikan siswa adalah sebagai berikut:

a. Kesalahan atau kesulitan siswa yang berkaitan dengan arti pecahan yang merupakan bagian dari keseluruhan utuh.

Kesalahan-kesalahan yang muncul antara lain adalah sebagai berikut:

(1) Meletakan angka yang seharusnya penyebut pada pembilang dan sebaliknya.

(2) Kesalahan dalam memahami maksud soal.

(3) Menyebutkan pecahan dari bagian yang tidak ditanyakan.

(4) Tidak merepresentasikan bagian-bagian dari keseluruhan utuh yang merepresentasikan suatu pecahan haruslah sama besar.

(5) Tidak dapat merepresentasikan pecahan yang ditentukan.

Kesalahan ini ditemukan pada jawaban beberapa siswa terhadap soal nomor 1, 2, dan 7. Kesalahan (1) terlihat dari jawaban beberapa siswa pada nomor 1 yang menjawab dengan $\frac{11}{4}$, seharusnya jawaban yang benar adalah $\frac{4}{11}$. Pada jawaban ini mereka menaruh 11 yang merupakan bagian dari keseluruhannya sebagai pembilang dan 4 merupakan bagiannya sebagai penyebut. Padahal seharusnya 11 diletakan pada penyebut dan 4 diletakan pada pembilang. Dalam pecahan $\frac{a}{b}, b$ (penyebut) menunjukkan berapa banyak bagian yang sama pada suatu keseluruhan utuh (whole), dan $a$ (pembilang) menunjukkan berapa banyak bagian (part) yang sama pada kuantitas pecahan yang ditunjukan oleh $\frac{a}{b}$ (Battista, 2012; Hurst dan Hurrel, 2014; Smith dalam Westenskow, 2012).

Soal no 1 .

Hindun mempunyai sebatang coklat. Kemudian ia membaginya menjadi 11 bagian sama besar. 4 bagiannya ia berikan kepada Ani. Berapa bagian dari seluruh coklat Hindun, coklat yang diberikan kepada Ani?

\section{Gambar 1. Soal Nomor 1}

Hasil wawancara beberapa siswa yang menjawab dengan jawaban di atas menunjukan bahwa mereka mengetahui maksud soal, namun salah merepresentasikan pecahan dengan meletakan angka yang seharusnya penyebut menjadi pembilang dan pembilang menjadi penyebut, hal ini dikarenakan pada saat mereka belajar mengenai pecahan tidak ditekankan bahwa penyebut menunjukan keseluruhan bagian yang sama dan pembilang menunjukan banyaknya bagian tertentu. Dengan demikian kesulitan ini tergolong pada didactical obstacle. Dalam pembelajaran pecahan sebaiknya didefinisikan dan dimaknai dengan jelas, menurut Wu (1998) tidak didefinisikan dan dimaknainya pecahan dengan jelas akan menimbulkan kebingungan dalam memahami rasio, proporsi, ataupun persen. 
Kedua, ditemukan kesalahan beberapa siswa akibat ketidak-telitian dalam memahami maksud soal, pada soal disebutkan kata "4 bagian diberikan kepada Ani", dengan adanya kata diberikan mereka berpikir bahwa harus ada operasi pengurangan dalam menyelesaikan soal tersebut, sehingga siswa menjawab sebagai berikut:

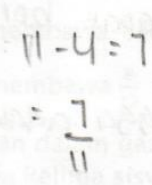

Gambar 2. Kesalahan Soal Nomor 1

Padahal yang ditanyakan kepada siswa adalah "berapa bagian yang diberikan kepada Ani dari keseluruhan coklat miliknya?", soal ini sama sekali tidak membutuhkan operasi pengurangan. Pengalaman siswa mengerjakan soal cerita ketika ada kata diberikan berarti penunjukan operasi pengurangan. Padahal pertanyaan yang diajukan bukanlah pertanyaan yang berkaitan dengan operasi pengurangan. Kesalahan ini terjadi akibat konteks soal yang diberikan kepada siswa berbeda dari biasanya, sehingga kesalahan ini termasuk pada epistemological obstacle.

Ketiga, sebagian siswa yang menjawab $\frac{7}{11}$ dengan melihat bagian lain selain yang ditanyakan, karena yang diberikan kepada Ani 4 bagian dari 11 bagian pecahan yang menunjukan hal itu dijawab dengan $\frac{7}{11}$. Hal ini diperkuat dengan pertanyaan yang dilontarkan kepada siswa ketika wawancara, siswa menjawab $\frac{3}{5}$ untuk soal dibawah ini.

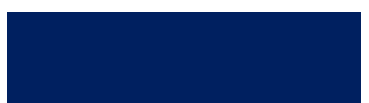

Ibu tanya, berapa bagian kotak berwarna biru dari keseluruhan bagian kotak?

Siswa melihat kotak selain warna biru untuk dijadikan penyebut, jawaban siswa tersebut akan benar jika yang ditanyakan adalah "berapa bagian kotak berwarna putih dari keseluruhan bagian kotak?". Hal ini semakin menunjukan bahwa penjelasan mengenai pembilang menunjukan bagian (part) yang dimaksudkan dan penyebut menunjukan keseluruhan utuh (whole) sangatlah penting diketahui oleh siswa. Dengan demikian kesalahan ini termasuk pada didactical obstacle.

Keempat, kesalahan akibat tidak merepresentasikan bahwa bagian-bagian untuk menunjukan pecahan haruslah sama besar, ini dilihat dari soal no 7. 


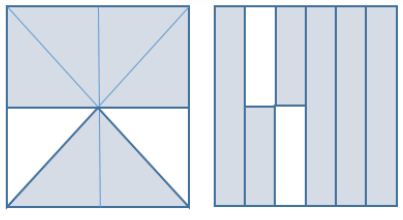

(a)

(b)

Rini dan Rina berdebat mengenai gambar diatas.

Rini mengatakan bahwa bagian yang diwarnai pada gambar (a)

dengan gambar (b) menunjukan pecahan yang sama, karena sama-

sama mempunyai dua buah bagian yang tidak berwarna.

Rina berpendapat bahwa apa yang dikatakan Rini salah, bahwa

bagian yang diwarnai pada gambar (a) dengan gambar (b)

menunjukan pecahan yang berbeda.

Bagaimana pendapatmu, apakah kamu setuju dengan apa yang

dikatakan Rina atau Rini, jelaskan alasannya!

\section{Gambar 3. Soal Nomor 7}

Sebagian besar siswa yang menjawab keliru soal melihat banyaknya daerah yang berwarna biru dan putih yang jumlahnya sama, tetapi tidak melihat ukuran bagian-bagian dari gambar, terutama pada gambar (b). Berikut adalah kutipan jawaban siswa:

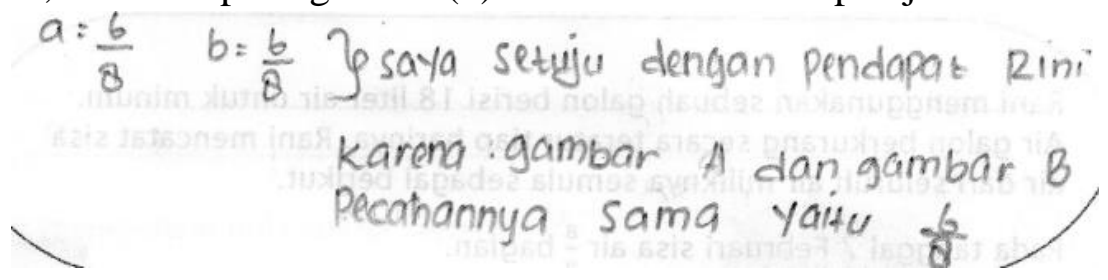

Gambar 4. Kesalahan Soal Nomor 7

Jika dilihat pada gambar 3 (b) menunjukan pecahan $\frac{5}{6}$ atau $\frac{10}{12}$, karena bagian-bagian yang terdapat pada gambar tersebut tidak sama besar, jadi siswa seharusnya menyamakan dahulu bagian-bagiannya. Hal ini dikuatkan pula oleh hasil wawancara yang menunjukan hal demikian. Pada pembelajaran pecahan sebelumnya siswa mengenal pecahan lewat contoh berikut:

\section{A. Mengenal Pecahan}

1. Mengenal Pecahan Sederhana (Misal: Setengah, Seperempat, Sepertiga, dan Seperenam)

Contoh:

Bentuk gambar dibagi sama dapat digunakan untuk menunjukkan pecahan

a.

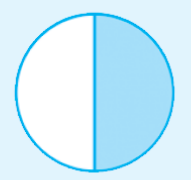

Daerah yang diberi warna adalah 1 bagian dari 2 . Oleh karena itu, daerah tersebut menunjukkan pecahan $\frac{\mathbf{1}}{\mathbf{2}}$.

Gambar 5. Materi Pengenaalan Pecahan

(Sumber: Fajriyah dan Triratnawati, 2008, hlm. 137) 
Oleh karena itu, penjelasan terhadap bagian yang seharusnya sama besar untuk menunjukan suatu pecahan haruslah tersampaikan dengan baik pada pembelajaran. Battista (2012) mengemukakan bahwa untuk memahami pecahan, siswa harus mampu untuk mempartisi keseluruhan menjadi bagian-bagian yang sama dan memahami bagaimana bagian tersebut terkait dengan keseluruhan. Dengan demikian kesalahan ini termasuk pada didactical obstacle.

Kelima, seluruh siswa tidak dapat menentukan bagian dari pecahan yang ditentukan. Hal ini terlihat dari jawaban siswa terhadap soal berikut.

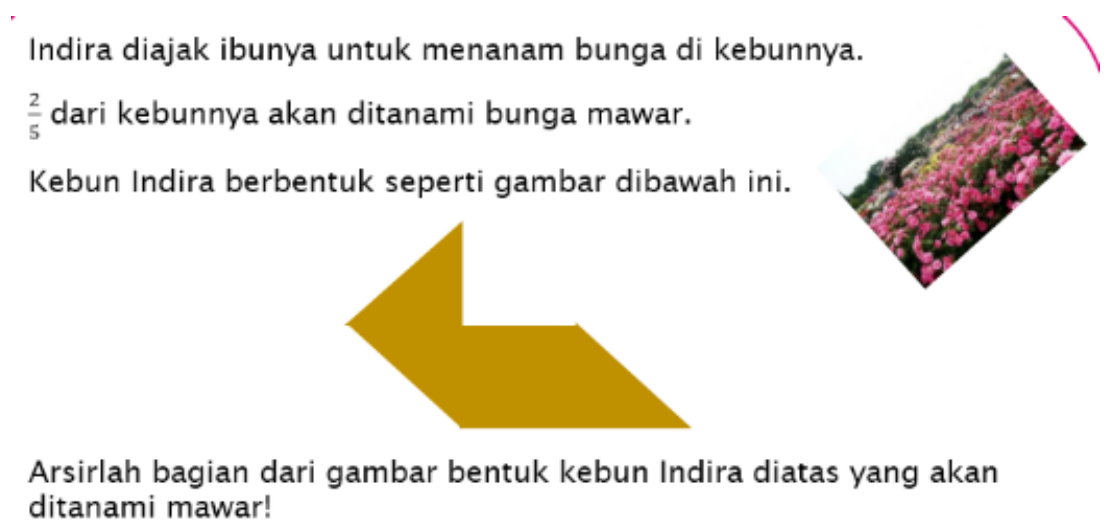

Gambar 6. Soal Nomor 4

Pada soal nomor 4 siswa tidak dapat menetukan bagian dari gambar yang akan ditanami mawar. Respon jawaban siswa pada soal ini adalah tidak mengarsir gambar yang diberikan, mengarsir namun tidak jelas berapa bagian yang diarsir, mengarsir dengan jelas ukuran yang diarsirnya namun menunjukan pecahan $\frac{3}{5}$ bukan $\frac{2}{5}$, mengarsir dengan membuat garis-garis pada seluruh daerah yang diarsir kemudian menghitung banyaknya garis yang dibuat. $\frac{2}{5}$ bagian dari gambar akan mudah ditentukan jika siswa membagi gambar menjadi lima bagian sama besar terlebih dahulu, tetapi pada pembelajaran siswa langsung diberi contoh seperti gambar 6 tidak melalui proses partisi terlebih dahulu. Selain itu, gambar yang harus diarsir merupakan gambar yang tidak biasa bagi siswa, karena biasanya contoh yang disodorkan adalah lingkaran ataupun bangun segi empat. Dengan demikian kesalahan ini terkategorikan pada didactical dan epistimological obstacle.

\section{b. Kesalahan atau kesulitan siswa yang berkaitan dengan arti pecahan yang merupakan bagian dari suatu kelompok tertentu.}

Kesalahan yang muncul antara lain adalah sebagai berikut:

(1) Meletakan angka penyebut sebagai pembilang dan sebaliknya.

(2) Menyebutkan pecahan dari bagian yang tidak ditanyakan.

Pertama, kesalahan meletakan angka yang seharusnya penyebut menjadi pembilang dan pembilang menjadi penyebut. Pada soal nomor 2 beberapa siswa menjawab $\frac{42}{7}$, yang seharusnya jawabannya adalah $\frac{7}{42}$. Soal nomor 2 dapat dilihat pada gambar 4.7 . 
Soal no 2.

Lina mempunyai bola coklat seperti gambar disamping ini.

Berapa bagian dari seluruh bola coklat Lina, bola coklat berwarna biru?

\section{Gambar 7. Soal Nomor 2}

Kedua, sebagian siswa menjawab $\frac{35}{42}$ sebagai jawabannya, karena melihat 7 buah bola coklat yang berwarna biru yang berarti sisanya 35, sehingga diputuskan bahwa bagian yang berwarna biru dari keseluruhannya adalah $\frac{35}{42}$. Siswa menyadari bahwa pertanyaan yang diajukan adalah bagian bola coklat yang berwarna biru dari keseluruhannya.

Kedua kesalahan ini sangat mirip dengan kesalahan pada soal no 1. Sehingga alasan yang mendasari kesalahan ini adalah kekeliruan dalam memahami arti pecahan. Apa yang ditunjukan oleh pembilang dan apa yang ditunjukan oleh penyebut tidak dijelaskan dengan baik pada siswa. Sehingga kedua kesalahan ini tergolong pada didactical obstacle.

\section{c. Kesalahan atau kesulitan siswa yang berkaitan dengan arti pecahan yang merupakan pembagian.}

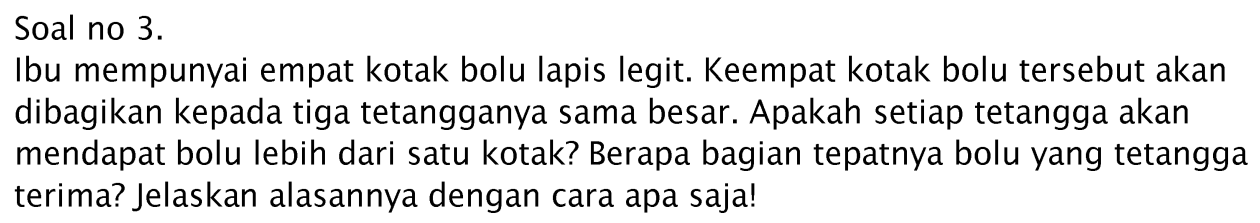

Gambar 8. Soal Nomor 3

Berdasarkan hasil jawaban siswa, 27\% siswa menjawab benar dengan konsep pembagian kemudian menghasilkan sebuah pecahan, $27 \%$ tidak menjawab soal, dan sisanya menjawab soal namun tidak tepat. Setelah diwawancara tidak ada masalah mengenai konsep pembagian dengan bilangan sederhana bagi siswa, namun pada soal ini karena 4 tidak habis dibagi 3 siswa kesulitan untuk mengerjakannya, sehingga beberapa siswa asal menjawab dan yang lainnya tidak mengerjakan soal tersebut. Pembagian bersisa sudah dipelajari di kelas IV sebelum mempelajari pecahan. Selain itu, dalam pembelajaran pecahan siswa jarang dihadapkan pada permasalahan yang seperti ini, arti pecahan yang merupakan pembagian tidak terepresentasikan dengan baik sehingga kesulitan ini termasuk pada didactical obstacle. Pembagian merupakan arti pokok dari pecahan kapanpun pecahan itu muncul (Wahyudin, 2013).

\section{d. Kesalahan atau kesulitan siswa yang berkaitan dengan pecahan senilai dan penyederhanaan pecahan.}

Soal no 6.

Arkan mempunyai 100 buah kelereng. 80 kelereng tersebut berwarna kuning. Teman-teman Arkan menyebutkan bagian kelereng berwarna kuning dari seluruh kelereng milik Arkan.

Sofwan mengatakan bahwa kelereng berwarna kuning milik arkan adalah $\frac{\mathbf{8 0}}{\mathbf{1 0 0}}$ bagian. Andi mengatakan bahwa kelereng berwarna kuning milik arkan adalah $\frac{20}{25}$ bagian. Noviandi mengatakan bahwa kelereng berwarna kuning milik arkan adalah $\frac{\mathbf{1 5}}{\mathbf{2 0}}$ bagian. Sandi mengatakan bahwa kelereng berwarna kuning milik arkan adalah $\frac{\mathbf{8}}{\mathbf{1 0}}$ bagian. Menurutmu siapa yang keliru menyebutkan pecahan yang menunjukan bagian kelereng berwarna kuning milik Arkan? 
Hampir 90\% lebih siswa menjawab soal ini dengan keliru. Perolehan hasil wawancara siswa memahami maksud dari soal yaitu mencari siapa yang keliru atau salah menyebutkan pecahan milik Arkan namun kesulitan dalam menentukan cara mengerjakan soal yang diberikan. Soal ini merupakan soal non rutin bagi siswa yang membutuhkan kemampuan mengevaluasi argumen serta menggunakan konsep pecahan senilai dan penyederhanaan pecahan. Akan lebih mudah bagi siswa untuk menentukan siapa yang keliru jika mereka sudah menemukan pecahan mana saja yang senilai dengan $\frac{80}{100}$. Siswa mengetahui cara mencari pecahan yang senilai, namun tidak dapat menerapkannya pada soal ini. Dalam pembelajaran pecahan siswa tidak diberikan permasalahan yang nyata atau berbentuk soal cerita mengenai penyederhanaan pecahan atau pecahan senilai. Oleh karena itu, kesulitan ini dapat dikategorikan pada epistemological obstacle dan didactical obstacle.

\section{e. Kesalahan atau kesulitan siswa yang berkaitan dengan pengurutan pecahan.}

\section{Soal no 7.}

Satu lusin pensil berisi 12 buah. Nadiah, Komala, Sari, Indi, Tuti membawa beberapa pensil ke sekolahnya. Nadiah membawa $\frac{4}{8}$ lusin pensil. Komala membawa $\frac{3}{4}$ lusin pensil. Sari membawa $\frac{8}{4}$ lusin pensil. Indi membawa 1 lusin pensil. Tuti membawa $\frac{8}{12}$ lusin pensil. Urutkan dalam garis bilangan dibawah ini banyaknya pensil yand9 dibawa kelima siswa tersebut! [Satuan dalam lusin]

\section{Gambar 10. Soal Nomor 7}

Tidak ada yang menjawab benar dalam mengerjakan soal nomor 7, baik dari segi mengurutkan pecahan maupun dari segi penempatan pecahan dalam garis bilangan. Soal ini menuntut siswa mengurutkan pecahan pada garis bilangan. Hasil wawancara menunjukan beberapa siswa mengerti bahwa cara mengerjakan soal dengan mengurutkan pecahan yang diberikan, karena sudah terpampang jelas dalam soal, namun tidak terpikirkan bagaimana mengurutkannya dalam garis bilangan. Dalam garis bilangan pecahan yang diurutkan dari keri ke kanan merupakan nilai bilangan kecil menuju besar. Selain itu, didalam pembelajaran siswa tidak pernah memprediksi dimana letak suatu pecahan dalam garis bilangan sehingga kesulitan ini terkategori pada didactical obstacle dan epistemological obstacle. Merepresentasikan pecahan sebagai bilangan pada garis bilangan tidaklah mudah dilakukan siswa sekolah dasar, namun hal ini penting karena garis bilangan sering digunakan di dalam atau di luar aljabar, bahkan garis bilangan dimanfaatkan dalam mempelajari penjumlahan dan pengurangan bilangan (Klein dan Beishuizen, 1998; Izsak, Tillema, dan Tung-Pekkan, 2008).

\section{f. Kesalahan atau kesulitan siswa yang berkaitan dengan penjumlahan dan pengurangan pecahan.}

Pertama, kesuliatan dalam merepresentasikan operasi hitung pecahan menjadi soal cerita atau model. 
Soal no 8 .

Buatlah soal cerita yang menunjukan jawaban dengan perhitungan dibawah ini:

$$
2 \frac{3}{4}-1 \frac{3}{12}=1 \frac{6}{12}
$$

Buat pula gambar untuk menunjukan perhitungan diatas!

\section{Gambar 11. Soal Nomor 8}

Sekitar $30 \%$ siswa mampu membuat soal cerita yang merepresentasikan pengurangan, tetapi tidak ada yang mampu membuat model dari soal tersebut. Berdasarkan hasil wawancara, siswa tidak menggunakan model untuk mengurangkan pecahan hanya diberikan pemahaman prosedural saja, selain itu siswa juga tidak pernah diminta membuat representasi dari sebuah operasi hitung. Padahal gambar dan manipulasi membantu menjelaskan mengapa dalam melakukan pengurangan dan penjumlahan pecahan tidak disertai dengan menambah atau mengurangi penyebut (Sonnabend, 2010). Menggunakan manipulasi (konkret ataupun virtual) dan menggunakan banyak representasi dari pecahan dianggap penting dalam mempelajari pecahan terlebih operasi pecahan. Taback (2001) menemukan bahwa merepresentasikan masalah menggunakan model yang berbeda dapat meningkatkan fleksibilitas siswa (Durmus dan Karakirik, 2006). Dengan demikian, kesulitan yang ditemukan pada siswa di soal ini, tergolong pada didactical obstacle.

Kedua, kesalahan yang muncul pada operasi hitung pecahan adalah kesalahan prosedural.

Soal no 9.

Nunik mempunyai $1 \frac{1}{3} \mathrm{~m}$ pita, kakaknya memberikan lagi $\frac{3}{8} \mathrm{~m}$ pita kepadanya.

Apakah pita yang dimiliki Nunik saat ini lebih dari $2 \mathrm{~m}$ ? Jelaskan!

[Kamu bisa menggunakan gambar, perhitungan dan lain sebagainya untuk menjelaskannya]

Gambar 12. Soal Nomor 9

Berdasarkan hasil wawancara dalam pembelajaran operasi pecahan siswa hanya diberikan prosedur operasi hitung penjumlahan atau pengurangan kemudian menghapalnya, sehingga kadang ada salah satu cara yang terlewat. Tidak dengan representasi dari penjumlahan pecahan tersebut, pun juga tidak dengan pemaknaan bahwa proses operasi itu sebenarnya melibatkan pecahan yang senilai. Oleh karena itu, hal ini merupakan didactical obstacle.

Ketiga, dalam masalah yang melibatkan pola dan konsep pengurangan pecahan dengan penyebut sama.

Soal no 10.

Rani menggunakan sebuah galon berisi 18 liter air untuk minum. Air galon berkurang secara teratur tiap harinya. Rani mencatat sisa air dari seluruh air miliknya semula sebagai berikut. Pada tanggal 7 Februari sisa air $\frac{8}{9}$ bagian. Pada tanggal 8 Februari sisa air $\frac{7}{9}$ bagian. Pada tanggal 9 Februari sisa air $\frac{2}{3}$ bagian. Pada tanggal 10 Februari sisa air $\frac{5}{9}$ bagian. Dan seterusnya. Pada tanggal dan bulan apa air tersebut akan habis? 
Kesulitan yang muncul adalah siswa tahu bagaimana cara mengurangkan pecahan dengan penyebut yang sama, tetapi tidak bisa menggunakannya pada permasalahan yang diberikan. Siswa memahami apa yang ditanyakan soal yaitu kapan air galon tersebut akan habis, namun karena jarangnya siswa menemui soal yang mempunyai banyak informasi, ditambah siswa harus mengeneralisasi pola yang ada untuk menentukan berapa bagian air yang berkurang tiap harinya, barulah menggunakan operasi pengurangan untuk menentukan jawabannya, siswa tidak dapat mengerjakan soal ini. Oleh karena itu, hal ini tergolong pada epistimological obstacle.

\section{KESIMPULAN}

Berdasarkan hasil tes dan wawancara siswa diperoleh kesimpulan bahwa ditemukan dua buah learning obstacles yaitu:

1. Didactical obstacles teridentifikasi dari kesalahan-kesalah pengerjaan soal yang diakibatkan oleh bagaimana siswa belajar dan bahan ajar yang digunakan siswa seperti pembelajaran pecahan yang tidak mendefinisikan pecahan secara jelas dan menekankan pada pengetahuan prosedur prosedural, kemudian siswa tidak mempelajari pecahan lewat proses partisi terlebih dahulu, dimana mempartisi akan memudahkan siswa dalam mempelajari pecahan.

2. Epistimological obstacles muncul dari kesalahan-kesalah pengerjaan soal yang diakibatkan oleh keterbatasan konteks pengetahuan yang dimiliki siswa. Misalnya, pengertian pecahan yang merupakan bagian dari keseluruhan, siswa terbatas pada konteks tersebut tanpa memandang bagian-bagiannya sama besar/banyak atau tidak. Selain itu, pemahaman prosedur siswa mengenai penyederhanaan pecahan, pengurutan pecahan, serta pengurangan dan penjumlahan pecahan terbatas pada soalsoal tertentu. Ketika soal yang diberikan berbeda dari biasanya, terdapat siswa yang kurang memahami maksud soal.

\section{DAFTAR PUSTAKA}

Battista, M. T. (2012). Cognition-based assessment \& teaching of fraction: building on students' reasoning. Portsmouth: Heinemann

Brousseau. (2002). Theory of didactical situations in mathematics. Netherlands: Kluwer.

Cortina, J. L., Visnovska, J, \& Zuniga, C. (2014). Unit fractions in the context of proportionality: Supporting students' reasoning about the inverse order relationship. Mathematics Education Research Journal. DOI: 10.1007/s13394-013-0112-5

Cortina, J. L., Visnovska, J., \& Zuniga, C.(2014). Equipartition as a didactical obstacle in fraction instruction. Acta Didactica Universitatis Comenianae Mathematics, Issue $14,1-18$

Durmus, S. \& Karakirik, E. (2006). Virtual manipulatives in mathematics education: A theoretical framework. Turkish Online Journal of Educational Technology, 5(1), 117-123. http://www.tojet.net/articles/v5i1/5112.pdf

Fajriyah, N. \& Triratnawati, D. (2008). Cerdas berhitung matematika untuk SD/MI kelas 3. Jakarta: Grahadi.

Hurst, C. \& Hurrell, D. (2014). Developing the big ideas of number. International Journal of Educational Studies in Mathematics. ISSN: 2148 - 5984.

Izsak, A., Tillema, E., \& Tunc-Pekkan, Z. (2008). Teaching and learning fraction addition on number line. Journal for Research in Mathematics Education, 39(1), 33-62. NCTM. 
Klein A. S., \& Beishuizen M. (1998). The Empty Number Line in Dutch Second Grades: Realistic Versus Gradual Program Design. Journal for Research in Mathematics Education. 29(4), 443-464.

Manno, G. (2005). Embadiment and a-didactical situation in the theaching-learning of the perpendicular straight lines concept. (Disertasi). Faculty of Mathematics and Physics Departement of Didactic Mathematics Comenius University Bratislava, Slovakia.

Nyikahadzoyi, M. R., Mapuwei, T., \& Chinyoka, M. (2013). Some cognitive obstacles faced by ' $A$ ' level mathematics students in understanding inequalities: a case study of Bindura urban high schools. International Journal of Academic Research in Progressive Education and Development, 2 (2). ISSN: 2226-6348

Pitta-Pantazi, D. (2014). Number teaching and learning. Dalam S. Lerman (penyunting). Encyclopedia of mathematics education (hlm.470-476). London : springer.

Prediger, S.(2008). The relevance of didactic categories for analysing obstacles in conceptual change Revisiting the case of multiplication of fractions. Learning and Instruction, 18(1), 3-17.

Sadi, A. (2007). Misconceptions in numbers. UGRU Journal, 5. hlm. 1-7.

Sonnabend T. (2010). Mathematics for teachers an interactive approach for grades $K-8$. USA: Belmont.

Untari, E. (2013). Diagnosis kesulitan belajar pokok bahasan pecahan pada siswa kelas V Sekolah Dasar. Jurnal Ilmiah STKIP PGRI Ngawi. (13)1. Hlm. 1-8.

Wahyudin. (2013). Matematika Dasar Pengetahuan Bermuatan pedagogis: gagasan yang kuat untuk para guru. (interpreter). Bandung: Mandiri.

Westenskow, A.(2012). Equivalent fraction learning trajectories for students with mathematical learning difficulties when using manipulatives. All Graduate Theses and Dissertations. Paper 1368. http://digitalcommons.usu.edu/etd/1368

Wheeldon, D. A. (2008). Developing mathematical practices in a social context:an instructional sequence to support prospective elementary teachers' learning of fractions. (Disertasi). Department of Teaching and Learning Principles in the College of Education at the University of Central Florida, Orlando.

Wu, H. (1998). Teaching fractions in elementary school: A manual for teachers. [online]. Diakses dari: https://math.berkeley.edu/ wu/fractions1998.pdf 